\title{
The Emerging Issues and Impacts of Technology in Classroom Learning
}

\author{
https://doi.org/10.3991/ijet.v15i15.14175
}

\author{
Ahmad Zahir Wali ( $\left.{ }^{\varpi}\right)$,Ahmad Wali Popal \\ Kandahar University, Kandahar, Afghanistan \\ zahirwali@gmail.com
}

\begin{abstract}
This study investigates the technological trends used in the classes of post graduate students of Education Faculty, UiTM. It also explores the perceptions of the students on impacts and emerging issues of technology on their classroom learning. The study has employed a quantitative research design and has used a questionnaire as a research method to collect data. The data was collected from a sample of 30 post graduate students of Education Faculty, University Teknology Mara (UiTM). The findings show that social media, gamification, blended learning, E-books, remote learning and self-directed professional development are the technological trends used in post graduate classes of Education faculty, UiTM. The findings also indicate that technology has positively influenced the classroom learning of these students. Lastly, the results show that technology is not perceived as an emerging issue that would interfere or hinder the students learning in the classroom.
\end{abstract}

Keywords—Technology, classroom learning, impacts, emerging issues.

\section{Introduction}

Technology has been a part of everything we do as routine in today's world and people would not even imagine living a life without the current technological trends. Regardless of how and where technology has been used, one may not debate against the comfort and ease that technology has brought to different aspects of everyday life. Likewise, the integration of technology with classroom environment has also changed the ways we experience learning and teaching. [5] believe that it is not impossible to have classes without the current technology. Though, learning can still happen but there would be a huge gap between what students learn in their schools and how the world outside the classroom perceive socializing, making of meaning and accomplishments.

According to [5] technology not only makes it possible for us to have the old stuff taught in a new way, but it also gives us the potential to present the new stuff in a new way. Both students and teachers use technological devices to facilitate learning experience. Although a small number of people still feel reluctant for welcoming technology in everyday learning or teaching experience, yet evidence indicate that learning experience has greatly improved. [10] believes that technology plays a vital role by 
shifting traditionally teacher centered class to a student centered one. Some examples of classroom technology are computer, interactive whiteboard, classroom management system, student response system also called clickers, blogs, wiki, Really Simple Syndicate (RSS), multimedia publishing, Robots. There are tons of new and interesting ways of using these technological trends in everyday lesson plan [2].

With technology comes motivation to class that is very important when dealing with students of different types and learning styles especially those who are entitled at-risk [13]. Also, the factor of entertainment is embedded with technology that functions as an agent of motivation for students. Technological trends such as audio visual materials, games, online web based activities, etc. may all be used to teach or learn in a class with higher level of motivated students.

\subsection{Research objectives}

This study aims:

- To find out the specific forms of technology used in the post graduate students' classes of education faculty, UiTM.

- To explore the impacts of technology in classroom learning

- To identify emerging issues of technology in classroom learning

\subsection{Problem statement}

Technology has been a very significant phenomenon in education in terms of facilitating both learning and teaching experience in classroom environment. Both teachers and students have redefined their roles for the best with the integration of technology to the classroom. Despite the significant role technology plays in facilitation of learning and teaching, still not all the current technological trends compatible with classroom environment are available in most classes of colleges or universities around the world. There are still classes that are fully teacher dominated, lecture based and teacher centered with no or limited integration of technology in classes. Out of the numerous factors that hinder the integration of technology in classroom environment, teachers' resistance to embed technology in their classes is considered to be a significant one and it is due to the fact that teachers who don't welcome technology in their classes are not into technology or they are not familiar with its use to a certain level. [9] stated that technology's benefits to students and their learning cannot be debated against, but the problem that continue to persist is teachers' lack of knowledge on the meaningful use of technology for their instruction. The findings of a study by [11] also revealed that lack of teachers who were not qualified in the use of technology was one of the several challenges that hindered technology integration at school level. In order for teachers to confidently use technology in their classes for instruction purposes, there should be simultaneous innovations happening in the provisions of technology and they have to be properly trained pedagogically for the use of the technological tools [12]. As limited or no research has been done to study the perception of Post graduate students perception of Education Faculty, UiTM towards 
the impacts and emerging issues of technology in classroom learning, thus this study would provide an understanding of how the technology is perceived by students in terms of helping them in their classroom learning and it will also help us understand whether technology leads to the emergence of issues that are considered to hinder classroom learning in some way.

\subsection{Operational definition}

Emerging issue: An issue that come into existence or development is emerging issue according to www.dictionary.com website. In this study emerging issue refers to the any issue that comes into existence and causes interruption or hinders the normal process or activity.

\section{$2 \quad$ Literature Review}

[3] define classroom technology as the communication, technology and information integration in education through the computer-based communication usage in every day classroom teaching process. With students being engaged and more into technology, increase in technology integration in classes across the nation and textbook developers focusing more on providing computer based learning materials, it is vivid that in the past five years, tendency toward equipping classes with latest technology has increased dramatically [7]. According to Schmid and Abrami (as cited by, [7]) with technology it is possible to change the learning environment from passive to active where learners get to feel autonomy and more control of their learning.

Based on the findings of a study by [7], it is suggested that equipping those classes with technology that had no technology before, leaves positive impact on students' perception of teacher and their attitude. Meanwhile, taking away technology from classes that already had it installed will not negatively influence student's behavior entirely. The study results further explained that technology influences students' class preparation, focus, note taking, student's learning, motivation to take extra courses in relevant field, class room participation, course evaluation process and the teacher. On the contrary, [4] believes that despite there is high demand for integrating technology into classrooms in K-12 settings and classrooms of blended and flipped way and virtual learning are gaining more attention, still numerous teachers find it difficult to incorporate technology in their classes due to their perception of several barriers. These barriers are specifically identified by Kopcha (as cited by [4]) as teachers' vision, understanding, professional development, access to technology and time. [1] stated that with the integration of technology in education system, it is not wise to think that teachers will be replaced by technology. However, with all broad existence of technology in education, teacher's role has altered over the period of time. In fact by using the technological tools and resources, teachers use technology for their benefit in supporting them in their teaching. Latest technologies eases teachers to use recent learning theories and teaching practices such as cooperative learning, active learning and construction of knowledge. With the growing trend toward technology, 
teachers are going to take more the role of a facilitator while students are going to be more active learners within the education system. The technological tools will provide learners the opportunity to explore and access the abundant resources and let them improve their collaborative learning skills, critical thinking skills and ability to study more in details. As the educational software developers design and make their products based on the current teaching and learning theories, so In the future, as technology will be part of every classroom, educators have to look for those technologies that is compatible with their teaching approaches, curriculum and students' needs [1].

On the contrary, [6] believe that with more tendency toward technology integration in higher education system, an e-learning environment has gained more popularity but these e-learning technologies cannot insure quality learning process and may even limit students' interest and participation, increase distraction and negatively influence classroom participation. They further asserted that there are strong beliefs that technology engages students in learning and increases their enthusiasm, however, they counter this by stating that students engagement and namely enthusiasm for learning is mainly due to the entertaining characteristic of technology, not because students are focused on learning and this entertaining feature of technology possibly results in increased students distraction from their learning process. Likewise, Meierdiercks (as cited [6]) believes that with technology, students are developing an unhealthy habit of relying on technology and this harms the students' critical thinking, understanding and analyzing abilities due to the fact that technology has everything available and prepared for these individuals, all they have to do is find and use it.

A study by [8] showed similar results claiming that despite the fact that digital devices are crucial part of classroom learning, but when these devices are used for nonclassroom purposes, it obviously hinders the learning process within the classroom. He further added that an average number of students use technological devices such as smartphones, laptops and tablets and etc. for purposes other than class during classroom time such as, for entertainment, fighting boredom and staying connected with the rest of the world which makes it the main reasons for distracting students from staying focused in their classes.

\section{$3 \quad$ Methodology}

\subsection{Research design}

As the study aims to study the emerging issues and impacts of technology on classroom learning based on the perceptions of M.A Education Faculty students of UiTM, thus a quantitative research based survey design is employed which describe trends.

\subsection{The instrument}

A questionnaire was developed and used as a data collection tool for this study. The first section of the questionnaire contains questions related to the current technological trends usage in class. The second part contains questions about the impacts of 
technology in classroom learning. The last section identifies the emerging issues of technology in classroom learning.

\subsection{Population and sampling}

The population of this study is the M.Ed students of Education Faculty in University Teknologi Mara (UiTM), Shah Alam, Malaysia. Thirty students were randomly selected from the total population of 100 students.

\subsection{Data analysis}

Descriptive statistics were used to analyze data and find the relevant mean scores using SPSS software V24.

\subsection{Reliability and validity}

In order to insure the validity of the questionnaire, it was shared with two content expert professors at the Education Faculty of University Teknology Mara. After several reforms based on the feedback of the experts, its validity was insured. Moreover, the reliability of the questionnaire was checked using the Cronbach's alpha calculation of SPSS v24 software. Table 1 shows that a reliability analysis was carried out on the perceived task values scale comprising 27 total items. Cronbach's alpha for the first 6 items of the questionnaire is, $\alpha=0.643$, the Cronbach's alpha for the second 12 items reached, $\alpha=0.863$, and the remaining 9 items retained, $a=0.867$ Cronbach's alpha score. All items of the questionnaire appeared to be worthy of retention, resulting in decrease in the alpha if deleted.

Table 1. Reliability of the Questionnaire

\begin{tabular}{|l|c|c|c|}
\hline \multicolumn{1}{|c|}{ Variable } & N of Item & Item Deleted & Alpha \\
\hline Technological Trends used in classes & 6 & - & 0.643 \\
\hline Impacts of technology on classroom learning & 12 & - & 0.863 \\
Emerging issues of technology in class & 9 & & 0.867 \\
\hline
\end{tabular}

\section{$4 \quad$ Findings}

\subsection{Technological trends use in classes}

The first objective of the study investigated the technological trends that are used in the classes of Education Faculty, UiTM. The findings are presented as in Table 2. 
Table 2. Technological Trends use in Education Faculty, Uitm

\begin{tabular}{|l|c|c|}
\hline \multicolumn{1}{|c|}{ Technological trends used in classes } & Mean & Std. Deviation \\
\hline Social Media & 2.83 & .791 \\
\hline Gamification & 2.63 & 1.033 \\
\hline Blended Learning & 2.57 & 1.251 \\
\hline E-books & 2.50 & 1.167 \\
\hline Remote Learning (virtual Learning) & 2.50 & 1.196 \\
\hline Self-directed professional development & 2.23 & 1.040 \\
\hline
\end{tabular}

$1=$ never $2=$ once a week $3=$ two or three times a week $4=$ more than three times a week

Table 2 shows the mean scores for the use of Technological trends in the classes of Education Faculty, UiTM. Items which gained higher mean scores were identified as 'Social Media' ( $M=2.83, \mathrm{SD}=.791)$, 'Gamification' $(\mathrm{M}=2.63, \mathrm{SD}=1.033)$ and 'Blended Learning' ( $\mathrm{M}=2.57, \mathrm{SD}=1.251)$. Meanwhile, the three items with comparative lower mean scores were 'Self-directed professional development' $(\mathrm{M}=2.23$, $\mathrm{SD}=1.040)$, 'Remote Learning (Virtual Learning)' $(\mathrm{M}=2.50, \mathrm{SD}=1.196)$, and ' $\mathrm{E}-$ books' (M=2.50, $\mathrm{SD}=1.167)$.

It can be deduced from the findings that all the technological trends as presented in table 4.1 are used once a week by the M.A students of Education Faculty, UiTM.

\subsection{Impacts of technology on classroom learning}

The second objective of the study sought to find out the impacts of technology on classroom learning. The findings are as present in table 3

Table 3. Impacts of technology on classroom learning

\begin{tabular}{|l|c|c|}
\hline \multicolumn{1}{|c|}{ Impacts of technology on classroom learning } & Mean & Std. Deviation \\
\hline Eases the pressure on me as a learner & 3.43 & .728 \\
\hline Helps accommodate my personal learning styles & 3.40 & .770 \\
\hline Enhances my professional development & 3.40 & .770 \\
\hline Broadens learning opportunities for me & 3.37 & .809 \\
\hline $\begin{array}{l}\text { Gives me the opportunity to be information seeker instead of information } \\
\text { receiver. }\end{array}$ & 3.30 & .702 \\
\hline Improves my learning of critical concepts and ideas. & 3.27 & .740 \\
\hline $\begin{array}{l}\text { Promotes the development of communication skills (e.g., writing and } \\
\text { presentation skills). }\end{array}$ & 3.27 & .640 \\
\hline Motivates me to get more involved in learning activities. & 3.21 & .957 \\
\hline $\begin{array}{l}\text { Promotes the development of my interpersonal skills (e.g., ability to relate } \\
\text { or work with }\end{array}$ & 3.20 & .664 \\
\hline Makes me feel more competent as a learner & 3.20 & .805 \\
\hline Promotes greater peer collaboration & 3.10 & .548 \\
\hline Helps me stay connected with my instructors for learning purposes & 3.03 & .850 \\
\hline
\end{tabular}

$1=$ strongly disagree $2=$ disagree $3=$ agree $4=$ strongly agree

Table 3 shows the mean scores for impacts of technology on classroom learning. Items which gained higher mean scores were identified as 'Eases the pressure on me as a learner' $(\mathrm{M}=3.43, \mathrm{SD}=.728)$, 'Helps accommodate my personal learning styles' 
$(\mathrm{M}=3.40, \mathrm{SD}=.770)$ and 'Enhances my professional development' $(\mathrm{M}=3.40$, $\mathrm{SD}=.770)$. Meanwhile, the three items with comparative lower mean scores were 'Helps me stay connected with my instructors for learning purposes' $(M=3.03$, $\mathrm{SD}=.850)$, 'Promotes greater peer collaboration' $(\mathrm{M}=3.10, \mathrm{SD}=.548)$, and 'Makes me feel more competent as a learner' $(\mathrm{M}=3.20, \mathrm{SD}=.805)$.

It can be deduced from the findings that on average the students agree to all the impacts of technology to their classroom learning as presented in table 3.

\subsection{Emerging issues of technology in classroom}

The third objective of the study investigated the emerging issues of technology in classroom. The findings are as present in Table 4.

Table 4. Emerging issues of technology in classroom

\begin{tabular}{|l|c|c|}
\hline \multicolumn{1}{|c|}{ Emerging issues of technology in classroom } & Mean & Std. Deviation \\
\hline Technology provide a disconnect of students from face to face social activities & 3.67 & 1.213 \\
\hline Students do not have equal access to technological resources & 3.57 & 1.194 \\
\hline $\begin{array}{l}\text { Takes away learning time: if teachers and students are not experienced with } \\
\text { technology in classroom, valuable time is wasted on technical troubles }\end{array}$ & 3.43 & 1.223 \\
\hline Technology can foster more cheating in class and on assignments & 3.33 & 1.124 \\
\hline Teachers lack of technological knowledge results in poor teaching & 3.30 & 1.055 \\
\hline Laptop uses by other students interrupt non laptop users during lecture & 3.27 & .868 \\
\hline $\begin{array}{l}\text { Increased distraction: technology is welcomed by students due to its entertain- } \\
\text { ing factor }\end{array}$ & 3.23 & 1.006 \\
\hline $\begin{array}{l}\text { Decrease critical thinking, analyzing and understanding skills: everything is } \\
\text { available all u have to do is choose }\end{array}$ & 2.77 & 1.135 \\
\hline Decreased classroom participation & 2.73 & .868 \\
\hline
\end{tabular}

$1=$ strongly disagree $2=$ disagree $3=$ somewhat agree $4=$ agree $4=$ strongly agree

Table 4 shows the mean scores for "Emerging Issues of Technology in Classroom". Items which gained higher mean scores were identified as 'Technology provide a disconnect of students from face to face social activities' $(\mathrm{M}=3.67, \mathrm{SD}=1.213)$, 'Students do not have equal access to technological resources' $(M=3.57, S D=1.194)$ and 'Takes away learning time: if teachers and students are not experienced with technology in classroom, valuable time is wasted on technical troubles' $(M=3.43$, $\mathrm{SD}=1.223$ ). Meanwhile, the three items with comparative lower mean scores were 'Decreased classroom participation' $(\mathrm{M}=2.73, \mathrm{SD}=.868)$, 'Decrease critical thinking, analyzing and understanding skills: everything is available all $\mathrm{u}$ have to do is choose' $(\mathrm{M}=2.77, \mathrm{SD}=1.135)$, and 'Increased distraction: technology is welcomed by students due to its entertaining factor' $(\mathrm{M}=3.23, \mathrm{SD}=1.006)$.

The findings suggest that on average the students do not show their agreement to the emerging issues of technology in classroom learning which means that students do not perceive any significant side effects of technology that would negatively influence their learning. 


\section{Discussion}

The findings indicate that most of technological trends are used once a week on average in all post graduate classes of Education faculty, UiTM. It was also found that classroom technology helps students in their classroom learning to a greater extent. These findings are in agreement with the findings of a study conducted by [7] in which it is found that equipping classes with technology will result in students' positive attitude towards their learning and teacher. However, taking away technology from classes in which technology is already available will negatively influence on learner's learning performance. Finally, the findings showed that no significant emerging issues of technology have been identified by the students that is perceived to be a challenge or interruption to the classroom learning. In fact, the participants of the study found technology to be of great benefit when it comes to aiding their classroom learning.

- Based on the findings of this study, it is suggested that faculties should always be in search to introduce the current technological trends compatible with classroom environment. It is effective in engaging learners in the learning and students find it helpful to work around technology as it aids their learning.

- Instructors should be the center of focus when it comes to introducing a new technology to the class. In fact, when teachers are trained for the certain usage of technology in class, there are more chances that the instructor will improvise new and interesting ways to incorporate more technology in their classes.

- Further research should be done in introducing the effective and successful practices of current technological trends usage in classroom environment. This would give faculty and instructors the opportunity to pick and adopt the most successful practices in integrating technological trends in their classes.

\section{References}

[1] Cennamo, K., Ross, J., \& Ertmer, P. (2009). Technology integration for meaningful classroom use: A standards-based approach. Nelson Education.

[2] Chung, J. H. (2007). Integrating Technology into the Classroom.

[3] Ghavifekr, S., \& Rosdy, W. A. W. (2015). Teaching and learning with technology: Effectiveness of ICT integration in schools. International Journal of Research in Education and Science, 1(2), 175-191. https://doi.org/10.21890/ijres.23596

[4] Kelly, D. P. (2015). Overcoming Barriers to Classroom Technology Integration. Educational Technology, 55(2), 40-43

[5] Klopfer, E., Osterweil, S., Groff, J., \& Haas, J. (2009). Using the technology of today in the classroom today: The instructional power of digital games, social networking, simulations and how teachers can leverage them. The Education Arcade, 1, 20.

[6] Kulesza, J., DeHondt, I. I., \& Nezlek, G. (2011). More technology, less learning? Information Systems Education Journal, 9(7), 4

[7] Lavin, A. M., Korte, L., \& Davies, T. L. (2011). The impact of classroom technology on student behavior. Journal of Technology Research, 2, 1. 
[8] McCoy, B. (2013). Digital distractions in the classroom: Student classroom use of digital devices for non-class related purposes.

[9] Morehead, P., \& LaBeau, B. (2005). The continuing challenges of technology integration for teachers. Essays in Education, 15, 120-127.

[10] Muir-Herzig, R. G. (2004). Technology and its impact in the classroom. Computers \& Education, 42(2), 111-131.

[11] Ramorola, M. Z. (2013). Challenge of effective technology integration into teaching and learning. Africa Education Review, 10(4), 654-670. https://doi.org/10.1080/18146627.20 13.853559

[12] Wachira, P., \& Keengwe, J. (2011). Technology integration barriers: Urban school mathematics teachers' perspectives. Journal of Science Education and Technology, 20(1), 1725. https://doi.org/10.1007/s10956-010-9230-y

[13] Wali, A. Z., \& Saad, M. N. (2018). Exploring Teaching Practices That are Helpful in Addressing at-risk Students in Classroom.

\section{Authors}

Ahmad Zahir Wali is a full-time lecturer in the English Language and Literature Department of Education Faculty, Kandahar University. He has obtained Master of Education degree in Teaching English as a Second Language in 2019 from Universiti Teknologi Mara. His research interests include Teaching Methodologies, autonomous learning, and educational technology, teacher and students' behavior. (zahirwali@gmail.com)

Ahmad Wali Popal is working as lecturer at the Management and Business Administration department of Economics Faculty, Kandahar University. He has MSC degree in Economics and Management from Ruhr University, Bochum, Germany. (popalwali@gmail.com)

Article submitted 2020-03-11. Resubmitted 2020-04-10. Final acceptance 2020-04-10. Final version published as submitted by the authors. 